\title{
Exclusively endoscopic approach to treating gastric perforation caused by an intragastric balloon: case series and literature review
}

\section{다)(1) $\odot(9$}

\author{
Authors \\ Galvão Neto ${ }^{4}$, Eduardo Guimarães Hourneaux de Moura ${ }^{2}$ \\ Institutions \\ 1 Endoscopy Unit, Gastro Obeso Center, São Paulo, Brazil \\ 2 Gastrointestinal Endoscopy Unit, Hospital das Clínicas, \\ University of Sao Paulo School of Medicine, São Paulo, \\ Brazil \\ 3 Endoscopy Unit, Endogastro Rio, São Paulo, Brazil \\ 4 Florida International University, Miami, Florida, United \\ States
}

Sérgio Alexandre Barrichello Junior ${ }^{1}$, Igor Braga Ribeiro², Ricardo José Fittipaldi-Fernandez ${ }^{3}$, Ana Carolina Hoff ${ }^{3}$, Diogo Turiani Hourneaux de Moura², Mauricio Kazuyoshi Minata², Thiago Ferreira de Souza², Manoel dos Passos

submitted 14.6.2018

accepted after revision 31.7.2018

\author{
Bibliography \\ DOI https://doi.org/10.1055/a-0743-5520 | \\ Endoscopy International Open 2018; 06: E1322-E1329 \\ (c) Georg Thieme Verlag KG Stuttgart · New York \\ ISSN 2364-3722
}

\author{
Corresponding author \\ Igor Braga Ribeiro, MD, Av. Dr. Enéas de Carvalho Aguiar, \\ 255 - Instituto Central, Prédio dos Ambulatórios - \\ Pinheiros, CEP: 05403-000 São Paulo, SP, Brazil \\ Fax: +55-1130697579 \\ igorbraga1@gmail.com
}

\section{ABSTRACT}

Background and study aims Obesity is a serious disease, resulting in significant morbidity and mortality. Intragastric balloons (IGBs) have been in use since the 1980s. After the insertion of an IGB, complications such as migration of the device and even severe gastric perforation can occur, requiring laparoscopic surgery. Here, we report three cases of gastric perforation after IGB insertion. In all three cases, the perforation was successfully repaired through an exclusively endoscopic approach.

\section{Introduction}

Obesity is a serious disease, resulting in significant morbidity and mortality [1]. There are a number of measures to facilitate weight loss, ranging from dietary changes to endoscopic and surgical procedures [2-3].

Intragastric balloons (IGBs) have been in use since the 1980s [4-5]. During the evolution of IGB use, complications arose with the earlier, air-filled models, including leakage and migration of the device from the stomach into the small intestine, resulting in intestinal obstruction. Complications that are more serious, such as bleeding and gastric perforation, can also occur, especially during insertion or removal of the device [6-7].

Here, we report three cases of late gastric perforation after IGB insertion that were successfully treated using an exclusively endoscopic approach. This is the first report of use of this approach.

All procedures performed in this study were in accordance with the ethical standards of the institutional and/or national research committee and with the 1964 Helsinki declaration and its later amendments or comparable ethical standards. Informed consent was obtained from all individual participants included in the study.

\section{Case reports}

\section{Patient 1}

A 36-year-old woman with a body mass index (BMI) of $34 \mathrm{~kg} / \mathrm{m}^{2}$ (class I obesity) who had undergone placement of an IGB (Spatz3; Spatz FGIA, Inc., Great Neck, New York, United States) 5 months prior presented to the emergency room with moderate epigastric pain. She had not previously undergone gastric manipulation. She had stopped taking the prescribed proton pump inhibitor, of her own volition, 3 months prior to seeking treatment. An x-ray of the abdomen revealed no abnormalities. After analgesia, she presented improvement and was discharged. 


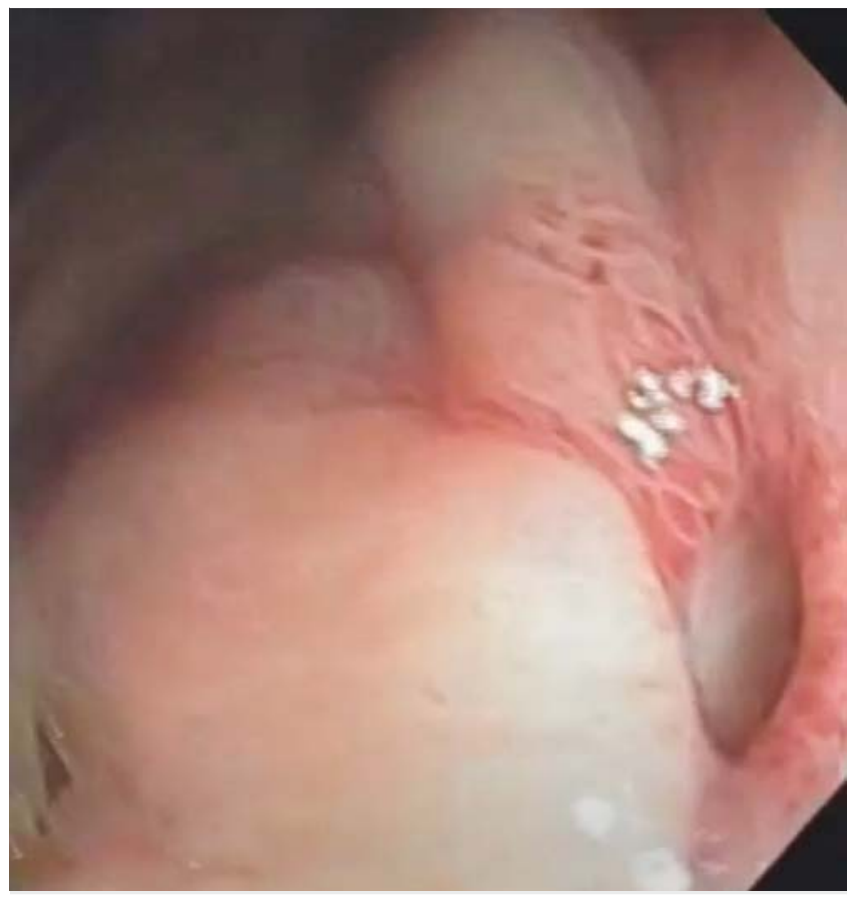

Fig. 1 Perforation.

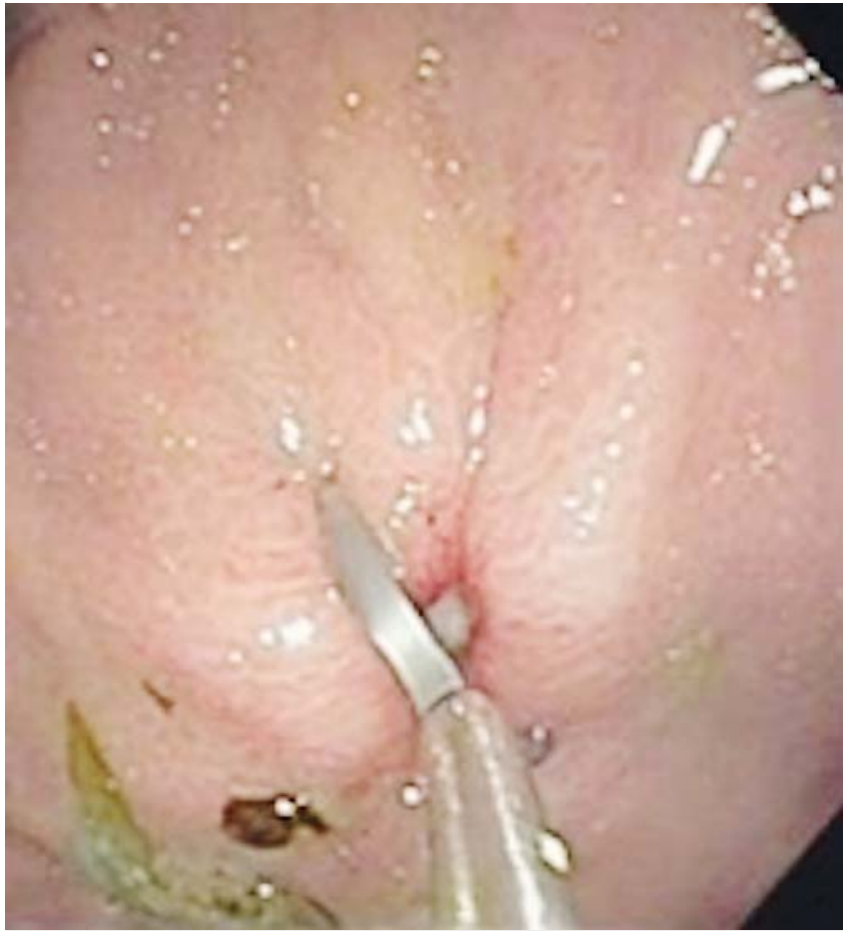

Fig. 2 Closure of the ulcer with clips.

The woman returned to the emergency room 6 hours later because her pain had worsened. Physical examination revealed intense upper abdominal pain without peritoneal irritation. She was not febrile, and her heart rate was within normal limits. Computed tomography (CT) of the abdomen showe pneumoperitoneum in the subdiaphragmatic and subhepatic regions, without free fluid in the abdominal cavity. Laboratory tests showed a white blood cell (WBC) count of $12,000 / \mu \mathrm{L}$, without elevated proportions of band or segmented neutrophils, and a C-reactive protein (CRP) level of $2 \mathrm{mg} / \mathrm{dL}$.

Antibiotic therapy, water/electrolyte replacement, and analgesia were started. During upper gastrointestinal endoscopy, which was performed in the operating room, without $\mathrm{CO}_{2}$ insufflation, the IGB was removed. A deep ulcer, with a diameter of approximately $1 \mathrm{~cm}$, was identified in the anterior wall of the gastric body ( $\triangleright$ Fig. 1$)$. The orifice was closed with two hemoclips (Resolution; Boston Scientific, Natick, Massachusetts, United States), and the final appearance was satisfactory ( $\triangleright$ Fig. 2). There was no need for intensive care unit (ICU) admission.

On post-procedure day 3, CT showed a slight increase in the pneumoperitoneum, without leakage of fluid into the cavity. At that time, the WBC count was $14,000 / \mu \mathrm{L}$, still without elevated proportions of band or segmented neutrophils, and the CRP level was down to $1.2 \mathrm{mg} / \mathrm{dL}$. The patient was still afebrile and showed no abdominal pain on palpation. She was started on a liquid diet, which was well accepted. On post-procedure day 5, the patient was discharged with a prescription for an oral antibiotic, the liquid diet being maintained.

\section{Patient 2}

A 31 -year-old woman with a BMI of $31 \mathrm{~kg} / \mathrm{m}^{2}$ (class I obesity) who had undergone placement of an IGB (Corporea; Medicone, Cachoeirinha, Brazil) 6 days prior and was taking a proton pump inhibitor presented to the emergency room with a 6-hour history of mild but progressively increasing pain in her left shoulder. She had no history of gastric surgery.

The patient was in good general condition and afebrile, with a heart rate of $86 \mathrm{bpm}$ and a blood pressure of $120 / 75 \mathrm{mmHg}$. Physical examination revealed a flaccid, painless abdomen without signs of peritoneal irritation. An abdominal x-ray revealed no indication of pneumoperitoneum and showed the IGB within the gastric pouch. Her pain worsened, migrating to the left subcostal region.

After 12 hours of observation, the pain persisted, despite treatment with opioids, and a non-contrast-enhanced CT scan revealed a discrete left subdiaphragmatic liquid layer containing a small amount of air, which was also present in the perihepatic region ( $\vee$ Fig.3). The IGB was seen to be compressed against the anterior wall of the gastric body ( $>$ Fig. 4 ). Therefore, the patient was admitted. At admission, her leukocyte count was 12,900 cells $/ \mathrm{mm}^{3}$, with no left shift, and her CRP level was $3 \mathrm{mg} / \mathrm{dL}$.

We opted for introduction of broad-spectrum antibiotic therapy, to be followed by endoscopic management. During the endoscopy, which was performed with minimal insufflation of the gastric pouch, the IGB was removed. Insufflation with $\mathrm{CO}_{2}$ was not used.

Two shallow fibrin-coated ulcers $(3 \mathrm{~mm}$ and $7 \mathrm{~mm}$ in diameter, respectively), together with a perforating lesion (approximately $3 \mathrm{~mm}$ in diameter), were observed in the greater curvature of the stomach, extending toward the anterior gastric wall ( Fig.5). The lesion was closed with two hemoclips (Instinct; Cook Medical, Winston-Salem, North Carolina, United States), 


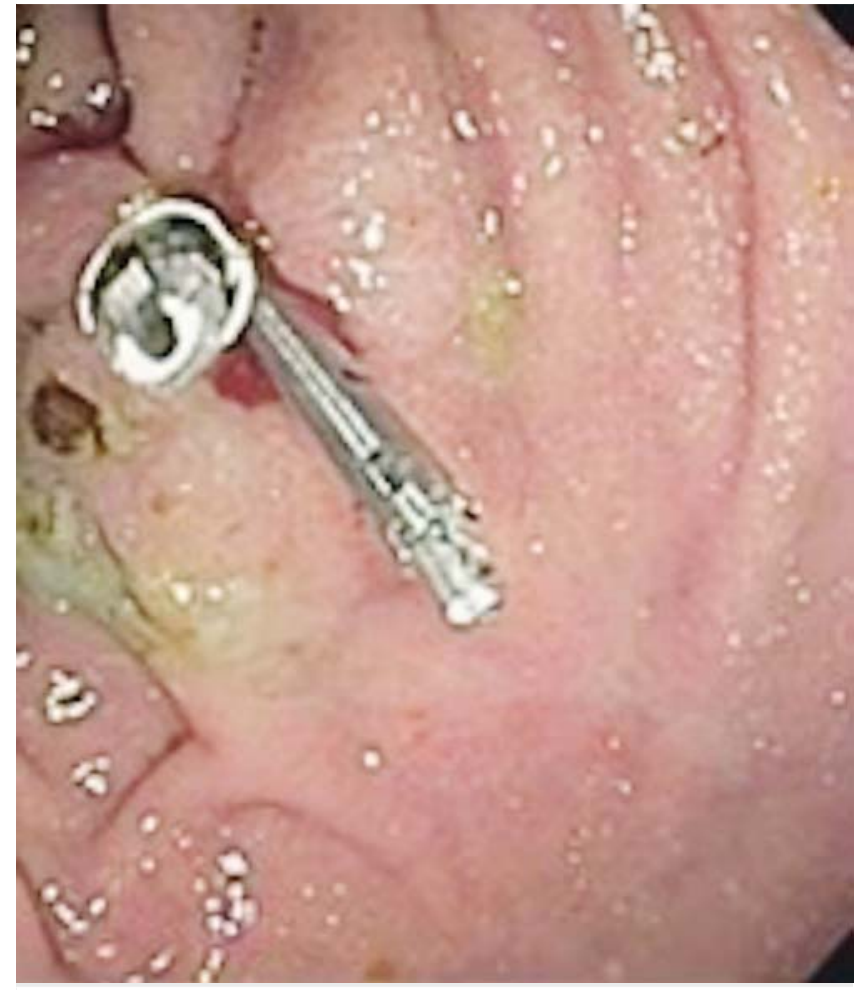

- Fig.3 Abdominal CT showing pneumoperitoneum.

and two more Instinct hemoclips were applied to the ulcers to prevent bleeding ( $\triangleright$ Fig.6). Post-procedure admission to the ICU was not necessary.

On post-procedure Day 1 , the patient's leukocyte count was 15,900 cells $/ \mathrm{mm}^{3}$, with $2 \%$ rods, her CRP level was $3 \mathrm{mg} / \mathrm{dL}$, and there was significant improvement in her abdominal pain.

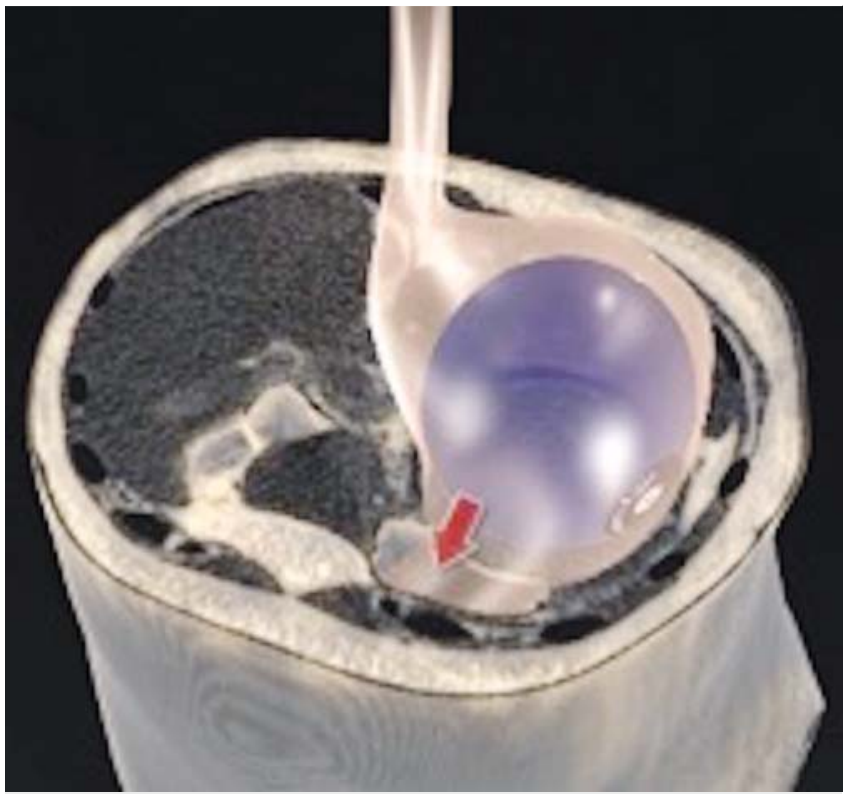

Fig. 4 Graphic representation of a balloon compressed against the anterior gastric wall.

At 48 hours after the procedure, oral contrast-enhanced CT showed a reduction in the pneumoperitoneum that was restricted to the left hypochondrium and epigastrium. There was no extravasation of the oral contrast agent.

At 72 hours after the procedure, the patient was free of complaints. She was started on a liquid diet, which was well accepted. Her leukocyte count was 14,900 cells $/ \mathrm{mm}^{3}$, with no shift, and her CRP level was $18 \mathrm{mg} / \mathrm{dL}$. The patient was discharged on Day 5 after admission. At this writing, she is in outpatient treatment and is still asymptomatic.
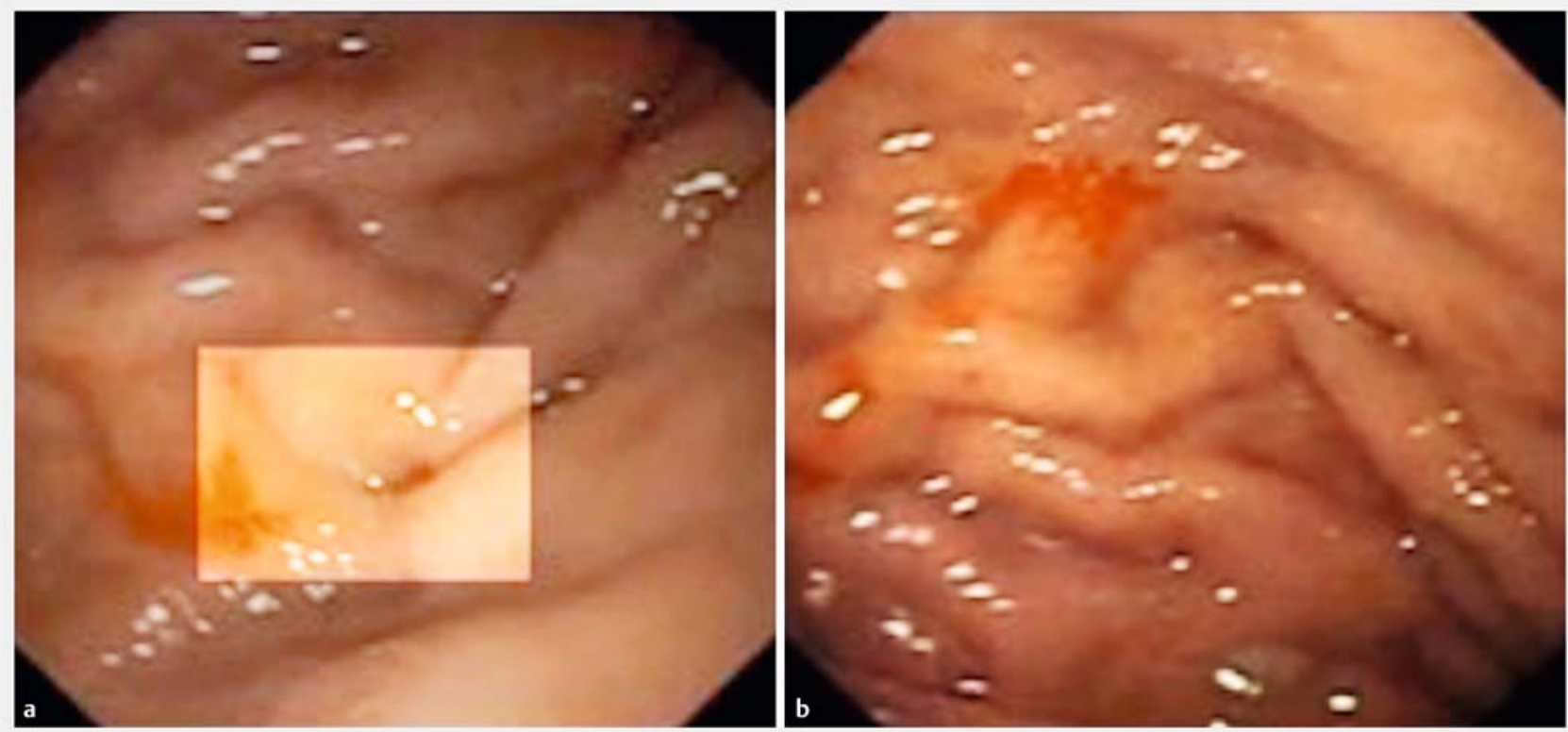

Fig. 5 Site of perforation in the anterior wall of the gastric body. 


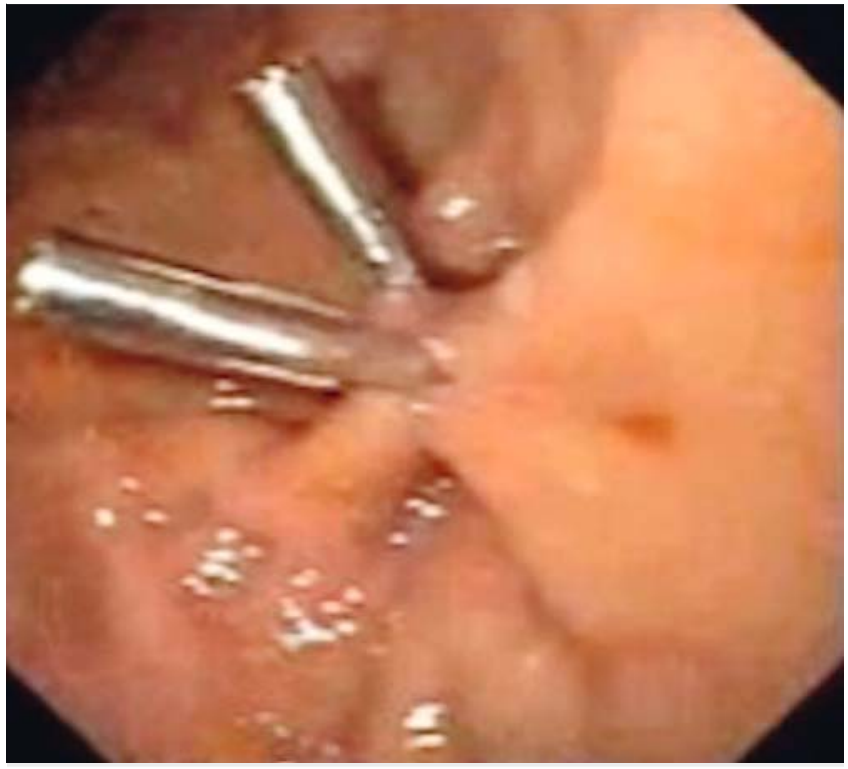

- Fig. 6 Exclusively endoscopic treatment with use of metal clips.

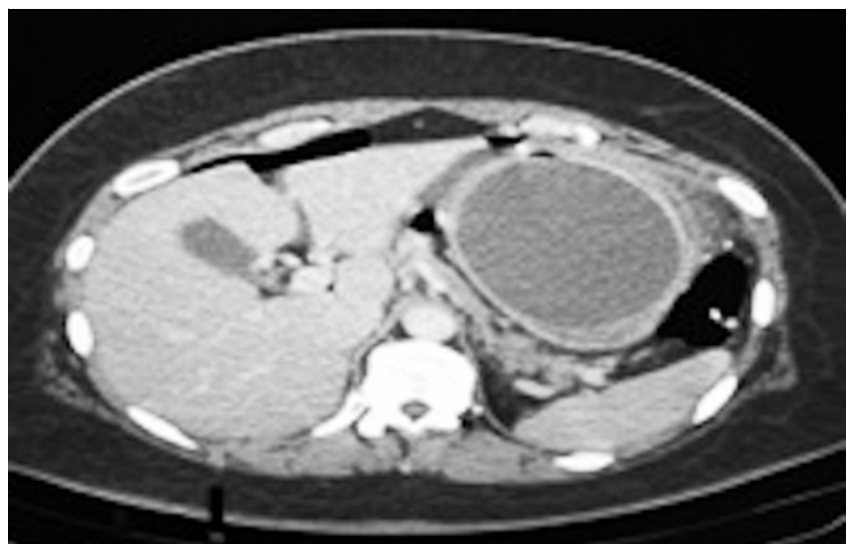

- Fig.7 CT showing pneumoperitoneum.

\section{Patient 3}

A 26 -year-old woman with a BMI of $38 \mathrm{~kg} / \mathrm{m}^{2}$ (class II obesity) who had undergone placement of an IGB (ORBERA; Apollo Endosurgery, Austin, Texas, United States) 5 months prior and had discontinued use of the prescribed proton pump inhibitor in the second post-procedure month developed severe upper abdominal pain, which prompted her to seek treatment in the emergency room. During the 5 months since the procedure, she had lost $30 \mathrm{~kg}$. She had no history of gastric surgery. On deep palpation, she showed pain in the upper abdomen, although without painful decompression and normal peristalsis. She was afebrile. Her leukocyte count was 9,000 cells $/ \mathrm{mm}^{3}$ and her CRP level was $7 \mathrm{mg} / \mathrm{dL}$.

The patient underwent a CT scan of the abdomen, which showed that the IGB was still intact within the gastric body, there was a large amount of residual food in her stomach, and there was pneumoperitoneum ( $\triangleright$ Fig.7), although no collections were seen. The IGB was removed by upper gastrointesti-

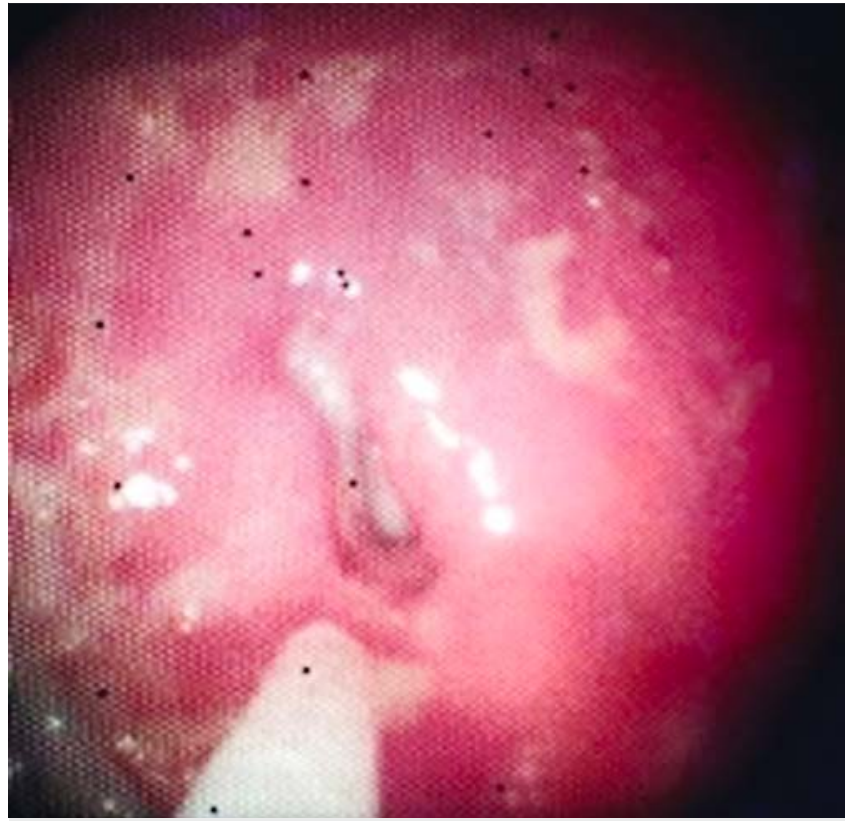

Dig. 8 Perforated ulcer.

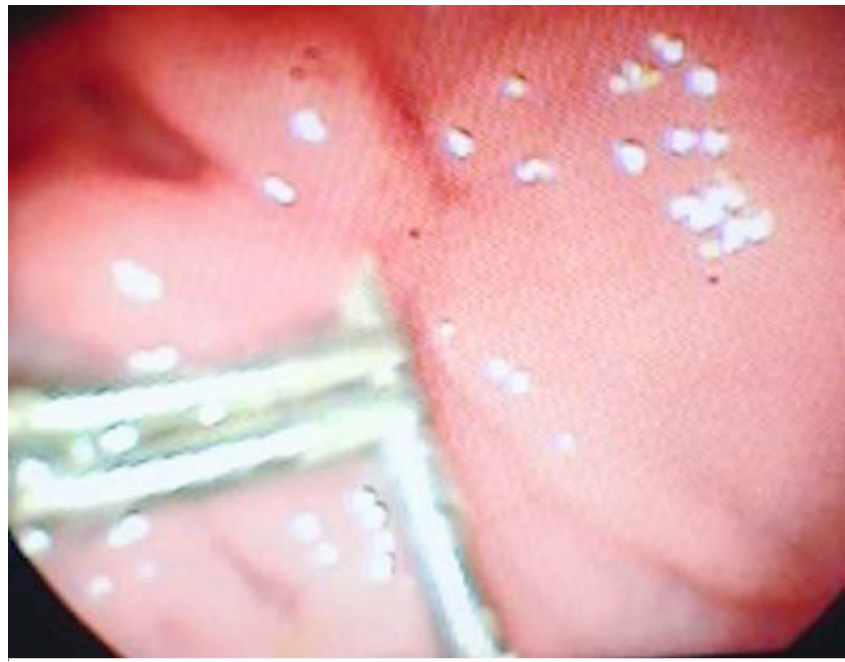

> Fig.9 Perforation.

nal endoscopy, which revealed a perforated ulcer of approximately $1 \mathrm{~cm}$ in diameter in the anterior wall of the gastric body ( $\triangleright$ Fig.8), into which the balloon was nestled. The decision was made to close the lesion with three metal clips (Resolution; Boston Scientific), as depicted in > Fig. 9.

After the procedure, the patient was admitted to the ICU, where she received no food or liquid by mouth and was started on intravenous antibiotic therapy. On post-procedure Day 4, her leukocyte count was 7,800 cells $/ \mathrm{mm}^{3}$ and her CRP level was $4 \mathrm{mg} / \mathrm{dL}$. Oral contrast-enhanced CT revealed no leakage into the abdominal cavity. The patient remained afebrile and her pain had lessened. On post-procedure Day 4, she was started on a liquid diet, which she tolerated well. On post-procedure Day 7 , the patient was discharged with instructions to remain on a soft diet until post-discharge Day 10 , when she could be- 
- Table 1 Patient characteristics.

\begin{tabular}{|l|l|l|l|}
\hline & Patient 1 & Patient 2 & Patient 3 \\
\hline Gender & Female & Female & Female \\
\hline Age & 36 & 31 & 26 \\
\hline Weight at balloon insertion & $87 \mathrm{~kg}$ & $74,5 \mathrm{~kg}$ & $94 \mathrm{~kg}$ \\
\hline BMI & $34 \mathrm{~kg} / \mathrm{m}^{2}$ & $31 \mathrm{~kg} / \mathrm{m}^{2}$ & $38 \mathrm{~kg} / \mathrm{m}^{2}$ \\
\hline Balloon Type & Spatz 3 & Medicone & Orbera \\
\hline Balloon volume & $500 \mathrm{~mL}$ & $600 \mathrm{~mL}$ & $600 \mathrm{~mL}$ \\
\hline Time of perforation occurence & $5 \mathrm{months}$ after balloon placement & 6 days after balloon placement & 5 Months after balloon placement \\
\hline PPI discontinued & Third month & Using PPI & Second month \\
\hline Time to perforation & 5 months & 6 days & 5 months \\
\hline
\end{tabular}

- Table 2 Summary of 15 studies reporting cases of gastric perforation following intragastric balloon insertion.

\begin{tabular}{|c|c|c|c|c|c|c|}
\hline Year & Author & Journal & History & $\begin{array}{l}\text { Time to } \\
\text { perforation } \\
\text { after balloon } \\
\text { insertion }\end{array}$ & Management & Outcome \\
\hline 2003 & $\begin{array}{l}\text { Roche-Nagle } \\
\text { et al. [33] }\end{array}$ & $\begin{array}{l}\text { Annals of the Royal College } \\
\text { of Surgeons of England }\end{array}$ & None & 2 months & Laparotomy & Recovery \\
\hline 2003 & $\begin{array}{l}\text { Giardiello } \\
\text { et al. [35] }\end{array}$ & Obesity Surgery & Fundoplication & 18 days & Laparotomy & Recovery \\
\hline 2005 & Genco et al. [24] & Obesity Surgery & $\begin{array}{l}\text { None }(n=1) \text {; } \\
\text { gastric surgery } \\
(n=4)\end{array}$ & - & $\begin{array}{l}\text { Laparotomy }(n=3) \text {; } \\
\text { and laparoscopy }(n=2)\end{array}$ & $\begin{array}{l}\text { Death }(n=2) \text {; and } \\
\text { recovery }(n=3)\end{array}$ \\
\hline 2009 & $\begin{array}{l}\text { Koutelidakis } \\
\text { et al. [36] }\end{array}$ & Obesity Surgery & None & 2 days & Laparotomy & Death \\
\hline 2009 & $\begin{array}{l}\text { Śmigielski } \\
\text { et al. [37] }\end{array}$ & Obesity Surgery & None & 9 days & $\begin{array}{l}\text { Laparoscopy+endos- } \\
\text { copy }\end{array}$ & Recovery \\
\hline 2010 & $\begin{array}{l}\text { Knoetze et al. } \\
{[38]}\end{array}$ & $\begin{array}{l}\text { Continuing Medical Educa- } \\
\text { tion }\end{array}$ & None & 7 months & Laparotomy & Recovery \\
\hline 2011 & Baigel et al. [39] & BMJ Case Reports & None & 22 months & Laparotomy & Recovery \\
\hline 2011 & $\begin{array}{l}\text { Sánchez-Pérez } \\
\text { et al. [40] }\end{array}$ & $\begin{array}{l}\text { Revista de Gastroentero- } \\
\text { logía de México }\end{array}$ & None & 2 months & Laparoscopy & Recovery \\
\hline 2012 & $\begin{array}{l}\text { Charalambous } \\
\text { et al. [41] }\end{array}$ & $\begin{array}{l}\text { Surgery for Obesity and } \\
\text { Related Diseases }\end{array}$ & None & 2 months & Laparoscopy & Recovery \\
\hline 2014 & Bekheit et al. [34] & Obesity Surgery & None & 2 months & Conservative & Recovery \\
\hline 2015 & $\begin{array}{l}\text { El Hage Chehade } \\
\text { et al. [42] }\end{array}$ & $\begin{array}{l}\text { Surgery for Obesity and } \\
\text { Related Diseases }\end{array}$ & $\begin{array}{l}\text { Sleeve } \\
\text { gastrectomy }\end{array}$ & Same day & $\begin{array}{l}\text { Laparotomy/subtotal } \\
\text { gastrectomy }\end{array}$ & Recovery \\
\hline 2016 & Dayan et al. [32] & Obesity Surgery & None & 10 months & $\begin{array}{l}\text { Laparoscopy+endos- } \\
\text { copy }\end{array}$ & Recovery \\
\hline 2016 & $\begin{array}{l}\text { Abou Hussein } \\
\text { et al. [43] }\end{array}$ & Obesity Surgery & None $(n=3)$ & $3,6,7$ months & $\begin{array}{l}\text { Laparoscopy+endos- } \\
\text { copy }\end{array}$ & Recovery \\
\hline 2017 & Yoo et al. [44] & Clinical Endoscopy & None & 2 months & Laparoscopy & Recovery \\
\hline 2018 & $\begin{array}{l}\text { Rahman } \\
\text { et al. [45] }\end{array}$ & $\begin{array}{l}\text { Surgery for Obesity and } \\
\text { Related Diseases }\end{array}$ & None & 13 months & Laparoscopy & Recovery \\
\hline
\end{tabular}


gin a solid diet. At 30 days after the procedure, upper gastrointestinal endoscopy showed complete closure of the orifice, with three clips still in place.

\section{Discussion}

Concern regarding obesity has been growing worldwide [8]. The first steps in treatment of obesity are always lifestyle changes, focusing on a balanced diet and increased physical activity. However, diet and pharmacological therapy are limited in their potential for achieving sustained weight loss, being effective in fewer than $5 \%$ of cases [9].

In contrast, bariatric surgery provides the most effective and prolonged response, in terms of weight loss, with excellent control of obesity-associated comorbidities [9-13]. However, indications for bariatric surgery are quite specific and it is not without risks [7, 14, 15].

Use of endoscopic procedures to control obesity can provide some of the benefits of bariatric surgery [16-17]. Such procedures have the advantages of often being reversible, having a lower risk profile, and being applicable in patients who are not candidates for laparoscopic or open surgery or who are at high surgical risk.

The first IGBs were introduced in the $1980 \mathrm{~s}$, and IGBs of one type or another have been used in clinical practice ever since [4-5]. Insertion of an IGB is expected to increase the sensation of satiety and to reduce oral food intake. The IGBs available have evolved significantly in recent years. Early models were inflated with air and had a limited $(200-220 \mathrm{~mL})$ final volume. Over time, it became apparent that use of IGBs had some potential complications. Due to their low resistance to the effects of gastric acid, earlier versions of IGBs lasted no more than 3 to 4 months [18]. The most common side effects associated with use of those IGBs were nausea, difficulty in inflating or deflating the balloon, unexpected deflation, and migration, any of which could lead to serious complications [19-21]. To address this concern, specialists organized a conference to determine the ideal characteristics of safe and effective IGB practice [19]. The recommended procedure is one in which the IGB is introduced endoscopically, after which it is filled with 400 to 700 $\mathrm{mL}$ of saline and methylene blue; the methylene blue is added because it changes the color of the urine if the balloon ruptures [5,22-23]. The current generation of IGBs includes devices with capacities of up to $960 \mathrm{~mL}$.

The number of adverse events (AEs) associated with IGB insertion varies across studies. In one clinical trial of IGB use, Genco et al. [24] observed no such events. In another such trial, Ponce et al. [25] reported 28 AEs. Of the eight randomized controlled trials of IGBs conducted to date, only six reported AEs, with a weighted mean incidence of $28.2 \%$. The weighted mean reported incidence of serious AEs was $10.5 \%$, initial removal of the device being required in three studies [20,26-27]. Severe AEs include persistent vomiting, abdominal pain, gastroesophageal reflux disease, deep ulcers, and perforation during endoscopy. Ulcers were reported in the studies conducted by Ponce et al. [25], Mohammed et al. [28], and Shelby et al. [29]. Although classified as a moderate AE, an ulcer, left untreated,

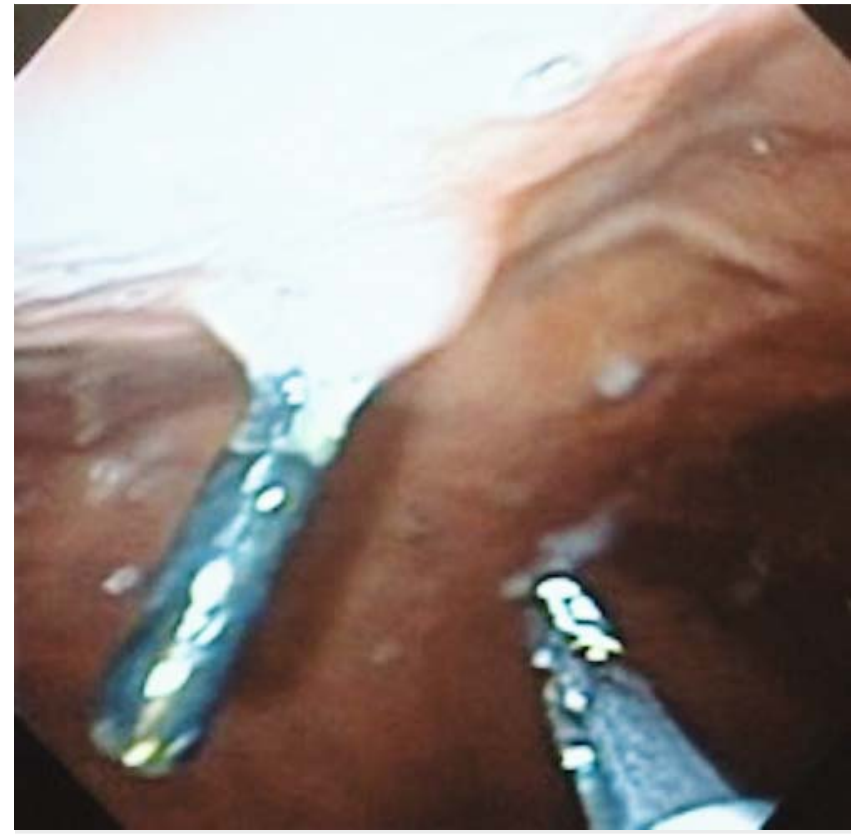

- Fig. 10 Endoscopy of case 2 to 6 months later.

can become life-threatening, especially if there is perforation. [30]

The mechanism by which IGB-induced perforation occurs is not well known. It is believed that an IGB causes perforation because it exerts constant pressure on and is in continuous contact with the gastric wall. One of the most common risk factors for perforation is poor adherence to or discontinuation of treatment with the PPI prescribed. Perforation can lead to peritoneal complications, which can be lethal [31]. Because there is limited evidence in the literature regarding the durability and efficacy of IGBs, the available studies having certain limitations, it is recommended that an IGB not be left in place for more than 6 months $[3,23,32]$. However, that time frame is not absolute, because most reported cases of IGB-induced perforation have occurred during the first 6 months after insertion of the device [32], as in all three of the cases described in the current study.

The first case of gastric perforation after IGB insertion was reported in 2003 [33].

In our case series, a different type of IGB was used in each of the three patients and scheduled to remain for 6 months. Against medical advice, two of the patients had discontinued use of the PPI, which could also be considered a major risk factor for IGB-induced perforation ( $\triangleright$ Table 1 ). All three patients were found to have an ulcer in the anterior gastric wall. Hospital stays did not exceed 7 days.

The usual treatment for IGB-induced gastric perforations is laparotomy for device removal and repair of the perforation. To our knowledge, this is the first report of such perforations being treated exclusively through endoscopy. In their case report, Mohamed et al. [34] also applied conservative treatment, although the treatment did not involve endoscopic interventions such as clip placement. In our review of the cases in the literature ( $\triangleright$ Table 2 ), we observed that, of the 21 patients 
who developed gastric perforation after IGB insertion, 3 (14.2\%) evolved to death.

In our patients, exclusive treatment by endoscopy was successful in removing the IGBs and effective in management of perforations. This was of great benefit, especially because a major operation (laparotomy) under general anesthesia could be avoided and early hospital discharge and consequently rapid return of the patients to their normal activities was faciitated.

All patients were followed up clinically monthly and endoscopically after 1 year. No symptoms were identified during the clinic follow-up. Two patients have had a normal upper gastrointestinal exam, with no scars. One patient underwent endoscopic sleeve gastroplasty after 1 year. During the pre-procedure endoscopy, one hemoclip was still in place ( $\mathbf{F i g . 1 0}$ ).

\section{Conclusion}

Exclusively endoscopic therapy for gastric perforations that occur after insertion of an IGB is possible in selected cases. use of this approach precludes the need for emergency surgery in such cases.

Competing interests

None

References

[1] Allison DB, Downey M, Atkinson RL et al. Obesity as a disease: A white paper on evidence and arguments commissioned by the council of the obesity society. Obesity 2008; 16: $1161-1177$

[2] Espinet-Coll E, Nebreda-Durán J, Gómez-Valero JA et al. Current endoscopic techniques in the treatment of obesity. Rev Esp Enfermedades Dig 2012; 104: 72 - 87

[3] Kumar N, Sullivan S, Thompson CC. The role of endoscopic therapy in obesity management: Intragastric balloons and aspiration therapy. Diabetes, Metab Syndr Obes Targets Ther 2017; 10: 311-316

[4] Gyring Nieben O, Harboe H. Intragastric balloon as an artificial bezoar for treatment of obesity. Lancet 1982; 319: 198-199

[5] Moura D, Oliveira J, De Moura EGH et al. Effectiveness of intragastric balloon for obesity: A systematic review and meta-analysis based on randomized control trials. Surg Obes Relat Dis 2016; 12: 420-429

[6] Saber AA, Shoar S, Almadani MW et al. Efficacy of first-time intragastric balloon in weight loss: a systematic review and meta-analysis of randomized controlled trials. Obes Surg 2017; 27: 277-287

[7] Ribeiro IB, Gestic MA, Utrini MP et al. Drain amylase levels may indicate gastrojejunostomy leaks after Roux-en-Y gastric bypass. Arq Gastroenterol 2018; 55: 66-72

[8] Lerner H, Whang J, Nipper R. Benefit-risk paradigm for clinical trial design of obesity devices: FDA proposal. Surg Endosc 2013; 27: 702 707

[9] Kumar N, Thompson CC. Endoscopic solutions for weight loss. Curr Opin Gastroenterol 2011; 27: 407-411

[10] Lee W-J, Lee Y-C, Ser K-H et al. Improvement of insulin resistance after obesity surgery: a comparison of gastric banding and bypass procedures. Obes Surg 2008; 18: 1119-1125
[11] Sjöström L, Lindroos A-K, Peltonen $M$ et al. Lifestyle, diabetes, and cardiovascular risk factors 10 years after bariatric surgery. N Engl J Med 2004; 351: 2683-2693

[12] Meek CL, Lewis HB, Reimann F et al. The effect of bariatric surgery on gastrointestinal and pancreatic peptide hormones. Peptides 2016; 77: $28-37$

[13] Ribeiro IB, Bernardo WM, Martins C et al. Colonic stent versus emergency surgery as treatment of malignant colonic obstruction in the palliative setting: a systematic review and meta-analysis. Endosc Int Open 2018; 5: E1 - E10

[14] Flum DR, Dellinger EP. Impact of gastric bypass operation on survival: A population-based analysis. J Am Coll Surg 2004; 199: 543 - 551

[15] Kakarla VR, Nandipati K, Lalla M et al. Are laparoscopic bariatric procedures safe in superobese (BMI $\geq 50 \mathrm{~kg} / \mathrm{m} 2)$ patients? An NSQIP data analysis Surg Obes Relat Dis7: 452-458

[16] Kumar N, Thompson CC. Endoscopic solutions for weight loss. Curr Opin Gastroenterol 2011; 27: 407-411

[17] Abu Dayyeh BK, Edmundowicz SA, Jonnalagadda S et al. Endoscopic bariatric therapies. Gastrointest Endosc 2015; 81: 1073-1086

[18] Gleysteen JJ. A history of intragastric balloons. Surg Obes Relat Dis 2016; $12: 430-435$

[19] Neto MG, Silva LB, Grecco E et al. Brazilian Intragastric Balloon Consensus Statement (BIBC): practical guidelines based on experience of over 40,000 cases. Surg Obes Relat Dis 2018; 14: 151-159

[20] Mathus-Vliegen EMH, Tytgat GNJ. Intragastric balloon for treatmentresistant obesity: safety, tolerance, and efficacy of 1-year balloon treatment followed by a 1-year balloon-free follow-up. Gastrointest Endosc 2005; 61: 19-27

[21] Madruga NetoAC, Bernardo WM, de Moura DT et al. The effectiveness of endoscopic gastroplasty for obesity treatment according to FDA thresholds: Systematic review and meta-analysis based on randomized controlled trials. Gastrointest Endosc 2018; 87: AB601

[22] Bernante P, Francini F, Zangrandi F et al. Green urine after intragastric balloon placement for the treatment of morbid obesity. Obes Surg 2003; 13: 951 - 953

[23] Tate CM, Geliebter A. Intragastric balloon treatment for obesity: review of recent studies. Adv Ther 2017; 34: 1859-1875

[24] Genco A, Cipriano M, Bacci V et al. BioEnterics ${ }^{\circledR}$ Intragastric Balloon $(B I B \otimes)$ : a short-term, double-blind, randomised, controlled, crossover study on weight reduction in morbidly obese patients. Int J Obes 2006; 30: 129-133

[25] Ponce J, Woodman G, Swain J et al. The REDUCE pivotal trial: A prospective, randomized controlled pivotal trial of a dual intragastric balloon for the treatment of obesity. Surg Obes Relat Dis 2015; 11: $874-881$

[26] Fuller NR, Pearson S, Lau NS et al. An intragastric balloon in the treatment of obese individuals with metabolic syndrome: A randomized controlled study. Obesity 2013; 21: $1561-1570$

[27] Abu Dayyeh BK, Eaton LL, Woodman G et al. 444 A randomized, multicenter study to evaluate the safety and effectiveness of an intragastric balloon as an adjunct to a behavioral modification program, in comparison with a behavioral modification program alone in the weight management of obese subjects. Gastrointest Endosc 2015; 81: AB147

[28] Mohammed MA, Anwar R, Mansour AH et al. Effects of intragastric balloon versus conservative therapy on appetite regulatory hormones in obese subjects. Trends Med Res 2014; 9: 58-80

[29] Sullivan S, Swain JM, Woodman G et al. The obalon swallowable 6 month balloon system is more effective than moderate intensity lifestyle therapy alone: Results from a 6-month randomized sham controlled trial. Gastroenterology 2016; 150: S1267 
[30] Ribeiro IB, Rezende DT, Madruga Neto AC et al. Endoscopic dual therapy for giant peptic ulcer hemorrhage. Endoscopy 2018: doi:10.1055/ a-0665-4142 [Epub ahead of print]

[31] Genco A, Bruni T, Doldi SB et al. BioEnterics intragastric balloon: The Italian experience with 2,515 patients. Obes Surg 2005; 15: 1161 1164

[32] Dayan D, Sagie B, Fishman S. Late Intragastric Balloon Induced Gastric Perforation. Obes Surg 2016; 26: 1138 - 1140

[33] Roche-Nagle G, Mulligan E, Connolly E et al. Unusual cause of a perforated stomach. Ann R Coll Surg Engl 2003; 85: 396 - 397

[34] Bekheit M, Abdelsalam WN, Sgromo B et al. Is conservative management for gastric perforation secondary to intragastric balloon possible? Case report and review of literature Obes Surg 2014; 24: 968 970

[35] Giardiello C, Cristiano S, Cerbone MR et al. Gastric perforation in an obese patient with an intragastric balloon, following previous fundoplication. Obes Surg 2003; 13: 658-660

[36] Koutelidakis I, Dragoumis D, Papaziogas B et al. Gastric perforation and death after the insertion of an intragastric balloon. Obes Surg 2009; 19: $393-396$

[37] Smigielski JA, Szewczyk T, Modzelewski B et al. Gastric perforation as a complication after BioEnterics intragastric balloon bariatric treatment in obese patients - synergy of endoscopy and videosurgery. Obes Surg 2010; 20: 1597 - 1599
[38] Knoetze R, van Mollendorff V, Yuen O. Gastric perforation as a complication of an intragastric balloon. Continuing Medical Education 2010; 28: 392

[39] Baigel R, Rashid F, Shrestha D etal. Peritonitis following a bariatric procedure in a young woman. BMJ Case Rep 2011 Feb 2011: 14

[40] Sánchez-Pérez MA, Muñoz-Juárez M, Cordera-González De Cosío F et al. Gastric perforation and subarachnoid hemorrhage secondary to intragastric balloon device. Rev Gastroenterol Mex 2011; 76: 264 269

[41] Charalambous MP, Thompson J, Efthimiou E. Late gastric perforation after insertion of intragastric balloon for weight lossvideo case report and literature review. Surg Obes Relat Dis 2012; 8: 121-123

[42] El Hage Chehade HH, El Khatib ZO, Abtar HK. What could happen if you insert a BioEnterics intragastric balloon after sleeve gastrectomy? Surg Obes Relat Dis 2015; 11: e39-e41

[43] Abou Hussein BM, Khammas AA, Al Ani AM et al. Gastric perforation following intragastric balloon insertion: combined endoscopic and laparoscopic approach for management: case series and review of literature. Obes Surg 2016; 26: 1127 - 1132

[44] Yoo IK, Chun HJ, Jeen YT. Gastric perforation caused by an intragastric balloon: endoscopic findings. Clin Endosc 2017; 50: 602-604

[45] Rahman AA, Loi K. Gastric perforation as a complication of intragastric balloon. Surg Obes Relat Dis 2018: 1 -4 